\title{
Abstract
}

This chapter explores ongoing shifts in the geometrical patterns of speech regulation in Europe. It first sets out the regulatory framework, which comprises an array of intertwined legally binding and political standards adopted by the Council of Europe and the European Union. It then explains how this framework has given rise to, and indeed encouraged, particular geometrical patterns in European lawmaking and policymaking. Those patterns have been shaped by an awareness that the mass media have been powerful actors in public debate, and that their freedom must be safeguarded — within certain agreed limits. They also demonstrate a concern that regulation should not curb the development of new information and communications technologies and services and new markets for such technologies and services. The chapter's next focus is the recent and ongoing shift in existing regulatory patterns, which entails a significant move towards foisting greater liability and responsibility on internet intermediaries for illegal third party content hosted by them or distributed via their services or networks. There is an emergent preference for self-regulatory codes of conduct as a regulatory technique. However, as this chapter will argue, the relevant European codes of conduct are less voluntary than they may ostensibly seem as recent codes of conduct seem to have a coercive undertone.

Keywords

freedom of expression, Europe, Council of Europe, ECHR, speech, intermediary liability, Delphi, AVMS 


\title{
CHAPTER 24
}

\section{Free Expression and Internet Intermediaries: The Changing Geometry of European Regulation}

\begin{abstract}
Tarlach McGonagle*
In Europe, as elsewhere in the world, the perennial political and scholarly debates about the regulation of expression continue unabated. Fuelled by an incessant stream of high-profile controversies, those debates focus increasingly on online expression. Do international human rights standards also apply (fully) in the online environment? Do they need to be rethought and repurposed? When does regulation for free expression pass the tipping point and tumble into regulation of free expression? Is it necessary, desirable, or even appropriate to have specific regulatory regimes for different types of media platforms in the online environment?
\end{abstract}

Questions such as these have been asked — and answered - repeatedly since the internet first emerged and progressively became a ubiquitous and indispensable medium for communication. Yet, in an environment that is so dynamic, it is important to keep asking — and answering — these questions, because it is not only the technologies themselves that change rapidly, but also the public's understanding of, trust in, and use of those technologies. These questions hover around the present chapter, which has been written at a moment

\footnotetext{
* This chapter repurposes, in places, some earlier work by the author on similar themes.
} 
of growing political and public pushback against the initial enthusiasm for, and uptake of, social networking, search, and other services offered by the 'big tech' companies.

The chapter explores ongoing shifts in the geometrical patterns of speech regulation in Europe. It first sets out the regulatory framework, which comprises an array of intertwined legally binding and political standards adopted by the Council of Europe and the European Union. It then explains how this framework has given rise to, and indeed encouraged, particular geometrical patterns in European lawmaking and policymaking. Those patterns have been shaped by an awareness that the mass media have been powerful actors in public debate, and that their freedom must be safeguarded — within certain agreed limits. They also demonstrate a concern that regulation should not curb the development of new information and communications technologies and services and new markets for such technologies and services.

The chapter's next focus is the recent and ongoing shift in existing regulatory patterns, which entails a significant move towards foisting greater liability and responsibility on internet intermediaries for illegal third party content hosted by them or distributed via their services or networks. There is an emergent preference for self-regulatory codes of conduct as a regulatory technique. However, as this chapter will argue, the relevant European codes of conduct are less voluntary than they may ostensibly seem. Whereas in the past, the encouragement by public authorities of self-regulation appeared to indicate a certain level of trust in a given sector to 'get its act together' and to 'get its own actors to step up to the plate', recent codes of conduct seem to have a coercive 
undertone. The subtext appears to read: if the codes of conduct are not adequately adhered to, sanctions will follow.

\section{THE EUROPEAN REGULATORY FRAMEWORK}

\subsection{The Council of Europe}

Article 10 of the European Convention on Human Rights (ECHR) is the centrepiece of protection for the right to freedom of expression in Europe. The European Court of Human Rights is the adjudicatory body formally tasked with the interpretation of the Convention, which binds all forty-seven Member States of the Council of Europe. The structure and scope of Article 10 ECHR are similar to those of Article 19 of the Universal Declaration of Human Rights and Article 19 of the International Covenant on Civil and Political Rights - the two leading provisions guaranteeing the right to freedom of expression in the United Nations' legal framework.

Article 10 ECHR opens with a broad statement of the right to freedom of expression in its first paragraph. It guarantees a composite right to freedom of expression. The component parts of the right are the freedom to hold opinions and to receive and impart information and ideas without interference by public authority and regardless of frontiers. But no sooner have these freedoms been set out, than they are reined in, as the text provides that states shall not be prevented from licensing 'broadcasting, television or cinema enterprises'. The second paragraph of Article 10 is a traditional claw-back clause. It provides that the right may be subject to certain limitations based on different enumerated grounds, such as 'the interests of national security, territorial integrity or public safety', 'the 
prevention of disorder or crime', and 'the protection of the reputation or rights of others'.

Article 10(2) justifies the permissibility of such limitations by linking them to the 'duties and responsibilities' that govern the exercise of the right. The scope of those duties and responsibilities varies, depending on the 'situation' of the person exercising the right and on the 'technical means' used. ${ }^{1}$ The Court usually explores the nature and scope of relevant duties and responsibilities not through broad principles, but on a case-by-case basis. It tends to distinguish among different professional occupations, such as journalism, politics, education, and military service. It also tends to distinguish between the perceived reach and influence of different media, such as the printed press, audiovisual media, and internet and social media. ${ }^{2}$

The Court has by and large interpreted Article 10 expansively and in a way that is faithful to the broad principles of freedom of expression. Its approach is, simply stated: the right to freedom of expression is the rule; any limitations on the right are the exception. When assessing whether an interference with the right to freedom of expression amounts to a violation of the right, the Court applies a standard test. It first establishes whether the impugned measure that has led to the interference with the right to freedom of expression is prescribed by law. It then determines whether the impugned measure pursues a legitimate aim (in the sense

${ }^{1}$ See Fressoz and Roire v France [GC] App. no. 29183/95 (ECtHR, 21 January 1999) para. 52.

${ }^{2}$ See Jersild v Denmark App. no. 15890/89 (ECtHR, 23 September 1994) para. 31. 
of Art. 10(2), see earlier). Thirdly, it assesses whether the impugned measure is necessary in a democratic society, corresponding to a pressing social need. The measure must furthermore be proportionate to the legitimate aim(s) pursued and the reasons given by state authorities for the measure must be 'relevant and sufficient'. The Court interprets the adjective 'necessary' in a strict fashion.

In practice, the Court has sought to interpret Article 10 ECHR in a way that ensures strong protection for freedom of expression and robust public debate. As the Court famously affirmed in its Handyside judgment, information and ideas which 'offend, shock or disturb the State or any sector of the population' must be allowed to circulate in order to safeguard the 'pluralism, tolerance and broadmindedness without which there is no "democratic society". ${ }^{3}$ Recent case law from the Court suggests that this so-called Handyside principle actually extends to much of the offensive, unsavoury, and vulgar content that is widely available on the internet. However, a red line marking the outer limits of protected expression can be traced around the contours of hate speech.

The term 'hate speech' does not appear in the text of the Convention. The Court has been using the term since 1999, but it has never defined the term. 'Hate speech' typically falls under Article 17-the Convention's 'Prohibition of abuse of rights' provision. Article 17 aims to prevent any state, group, or person from engaging in any activity (including expression) directed at the destruction of any of the rights enshrined in the Convention or the limitation of those rights to an extent greater than is provided for in the Convention. Article 17 can therefore be

${ }^{3}$ See Handyside v United Kingdom App. no. 5493/72 (ECHR, 7 December 1976) para. 49. 
seen as a safety valve that denies protection to acts that seek to undermine the Convention and go against its letter and spirit. In the past, the Court has applied Article 17 to ensure that Article 10 protection is not extended to racist, xenophobic, or anti-Semitic speech; statements denying, disputing, minimizing, or condoning the Holocaust, or (neo-)Nazi ideas. ${ }^{4}$ This means that, in practice, sanctions for racist speech do not violate the right to freedom of expression of those uttering the racist speech. In prima facie cases of hate speech, the Court will apply Article 17 in a straightforward fashion. This usually leads to a finding that a claim is manifestly ill-founded, and the claim is accordingly declared inadmissible. Such a finding means that the Court will not examine the substance of the claim because it blatantly goes against the values of the Convention. That is why Article 17 is sometimes referred to as a 'guillotine' provision. ${ }^{5}$ However, the criteria used by the Court for resorting to Article 17 (as opposed to Art. 10(2))

${ }^{4}$ See Tarlach McGonagle, 'The Council of Europe against online hate speech: Conundrums and challenges', Expert paper, doc. no. MCM 2013(005) (the Council of Europe Conference of Ministers responsible for Media and Information Society, 'Freedom of Expression and Democracy in the Digital Age: Opportunities, Rights, Responsibilities', Belgrade, 7-8 November 2013).

${ }^{5}$ See Françoise Tulkens, 'When to say is to do: Freedom of expression and hate speech in the case-law of the European Court of Human Rights' in Josep Casadevall, Egbert Myjer, Michael O’Boyle, and Anna Austin (eds), Freedom of Expression: Essays in honour of Nicolas Bratza (Wolf Legal Publishers, 2012) 284 . 
are unclear, leading to divergent jurisprudence. ${ }^{6}$ How the term 'hate speech' is understood and delineated is very important when it comes to determining what measures the media and internet intermediaries should take to counter types of expression that (may) amount to hate speech.

The Court has developed a corpus of case law from which it has distilled a set of key free expression principles relating specifically to the media and journalists. The Court considers public debate to be of paramount importance for wellfunctioning democratic societies. It has repeatedly recalled the important contributions that the media, journalists, and-increasingly-other actors can make to public debate. It has recognized that the media: disseminate information and ideas widely and thereby contribute to public opinion-forming; perform a public watchdog role by keeping governmental and other powerful forces in society under scrutiny; and create shared fora in which public debate can take place. It has held time and again that the public not only have the right to receive information about matters of general interest to society, but the media have the duty to impart such information. In order to enable the media to carry out the key roles ascribed to them in democratic societies, the Court has carved out specific freedoms for them, such as the protection of confidential sources, presentational and editorial freedom, freedom to report and comment-including with recourse to exaggeration and provocation.

${ }^{6}$ See Hannes Cannie and Dirk Voorhoof, 'The Abuse Clause and Freedom of Expression in the European Human Rights Convention: An Added Value for Democracy and Human Rights Protection?' (2011) 29 Netherlands Quarterly of Human Rights 54-83. 
With the advent and growing influence of the internet, the Court has had to figure out how far and how fast the principles it had developed for the media would travel in the online world. It has progressively recognized that the roles that were traditionally the preserve of the media and journalists can also be carried out — to varying degrees—-by a growing range of (non-media) actors. Examples include NGOs, academics, whistle-blowers, citizen journalists, bloggers, and ordinary individuals. ${ }^{7}$ The Court has identified a positive obligation for states under the ECHR to create a favourable environment for participation in public debate by everyone and to enable the expression of opinions and ideas without fear. ${ }^{8}$

To meet the challenge of applying its principles in the digital age, the Court has sought to stand firm on familiar shores, but it has also sought to set sail for and explore new horizons. This has led to an approach that could be described as 'adaptive replication'. The Court has sought to replicate its media freedom standards in respect of the internet, but in a way that is adaptive to distinctive features of the online environment.

${ }^{7}$ See, by way of indicative example, Magyar Helsinki Bizottság v Hungary [GC] App. no. 18030/11 (ECtHR, 8 November 2016).

${ }^{8}$ See Dink v Turkey App. nos 2668/07 and four others (ECtHR, 14 September 2010) para. 137. For analysis, see Tarlach McGonagle, 'Positive obligations concerning freedom of expression: mere potential or real power?' in Onur Andreotti (ed.), Journalism at risk: Threats, challenges and perspectives (Council of Europe Publishing 2015) 9-35. 
After a somewhat slow start, the Court is now steadily developing a corpus of 'internet' case law. A cornerstone of that case law is the acknowledgement that the internet 'has become one of the principal means for individuals to exercise their right to freedom of expression today: it offers essential tools for participation in activities and debates relating to questions of politics or public interest' ${ }^{9}{ }^{9}$ Thus, a measure resulting in the wholesale blocking of Google sites in Turkey 'by rendering large quantities of information inaccessible, substantially restricted the rights of Internet users and had a significant collateral effect' ${ }^{10}$ In a communications environment where the internet is of central importance, intermediaries have gained influence and power over the shaping public debate. The Court has described them as "protagonists of the free electronic media'11 and it has referred to the 'important role' played by information society service providers 'in facilitating access to information and debate on a wide range of political, social and cultural topics'. ${ }^{12}$

${ }^{9}$ See <ibt>Ahmet Ylldırım v Turkey App. no. 3111/10 (ECtHR, 18 December 2012)</ibt> para. 54 .

${ }^{10}$ ibid. para. 66 and Cengiz and Others $v$ Turkey App. nos 48226/10 and 14027/11 (ECtHR, 1 December 2015) para. 64.

${ }^{11}$ See Magyar Tartalomszolgáltatók Egyesülete and Index.hu Zrt v Hungary App. no. 22947/13 (ECtHR, 2 February 2016) para. 88 (and para. 69).

${ }^{12}$ Tamiz v United Kingdom App. no. 3877/14 (ECtHR, 12 October 2017) para. 90. 
All of this is in line with earlier observations by the Court that the internet is qualitatively different from other media technologies, 'in particular as regards the capacity to store and transmit information'. ${ }^{13}$ Nevertheless, the Court is clearly still navigating its way from the shoreline of familiar principles towards the new digital horizons. It still tends to measure new media against the yardstick of print and audiovisual media. As recently as 2013, it found that information on the internet and social media 'does not have the same synchronicity or impact as broadcasted information' ${ }^{14}$ It noted that notwithstanding 'the significant development of the internet and social media in recent years, there is no evidence of a sufficiently serious shift in the respective influences of the new and of the broadcast media in the [UK] to undermine the need for special measures for the latter' ${ }^{15}$ On the other hand, the Court has been willing to explore and accept the importance for free expression online of novel technological features of the new communications environment, such as hyperlinking. ${ }^{16}$

In the light of the complexity of the current-day communications environment, the Court has underscored the increased importance of the duties

${ }^{13}$ Editorial Board of Pravoye Delo and Shtekel v Ukraine App. no. 33014/05 (ECtHR, 5 May 2011) para. 63.

$14<$ ibt>Animal Defenders International v United Kingdom [GC] App. no. 48876/08 (ECtHR 2013) para. 119</ibt>.

15 ibid.

${ }^{16}$ See Magyar Jeti Zrt v Hungary App. no. 11257/16 (ECtHR, 4 December 2018). 
and responsibilities that govern the exercise of the right to freedom of expression and the pursuit of journalistic activities. ${ }^{17}$ It also sees it as a task for states' authorities to develop a legal (and policy) framework clarifying issues such as liability and responsibility. ${ }^{18}$

Whereas the Court's so-called internet case law generally extols the informational abundance and communicative potential of the medium, its judgment in Delfi AS v Estonia, which dealt with harmful aspects of online expression, threw a proverbial spanner in the works. ${ }^{19}$

In the case of Delfi ASv Estonia, the Estonian courts had held a large online news portal liable for the unlawful third party comments posted on its site in response to one of its own articles, despite having an automated filtering system and a notice-and-takedown procedure in place. Delfi removed the comments on the same day that it was requested to do so by the lawyer of the person most directly implicated by the comments. However, that was some six weeks after the publication of the article to which the comments reacted. The Grand Chamber of the European Court of Human Rights held that the national courts' finding of liability did not violate Delfi's right to freedom of expression under Article 10 ECHR. The Grand Chamber's findings were not unanimous, however: Judges Sajó and Tsotsoria penned a lengthy and very strongly worded joint dissenting opinion. The judgment has proved very controversial, particularly among free

${ }^{17}$ See Stoll v Switzerland [GC] App. no. 69698/01 (ECtHR, 10 December 2007).

${ }^{18}$ Inferred from Editorial Board (n. 13) para. 63.

${ }^{19}$ See <ibt>Delfi AS v Estonia [GC] App. no. 64569/09 (ECtHR, 16 June 2015)</ibt> 
speech advocates, who fear that such liability would create proactive monitoring obligations for internet intermediaries, leading to private censorship and a chilling effect on freedom of expression.

Several criticisms have been levelled at the Delfi judgment. First, the Court took the view that 'the majority of the impugned comments amounted to hate speech or incitements to violence and as such did not enjoy the protection of Article $10 ' .{ }^{20}$ By classifying the comments as such extreme forms of speech, the Court purports to legitimize the stringent measures that it sets out for online news portals to take against such manifestly unlawful content. The dissenting judges objected to this approach, pointing out that ' $[\mathrm{t}] \mathrm{hroughout}$ the whole judgment the description or characterisation of the comments varies and remains non-specific' and 'murky'.21

Secondly, the Court endorses the view of the Estonian Supreme Court that Delfi could have avoided liability if it had removed the impugned comments 'without delay'. ${ }^{22}$ This requirement is problematic because, as pointed out by the dissenting judges, it is not linked to notice or actual knowledge $\mathrm{e}^{23}$ and paves the way for systematic, proactive monitoring of third party content.

${ }^{20}$ ibid. para. 136.

${ }^{21}$ ibid. Joint Dissenting Opinion of Judges Sajó and Tsotsoria, paras 12 and 13, respectively.

22 ibid. para. 153.

${ }^{23}$ ibid. Joint Dissenting Opinion para. 8. 
Thirdly, the Court underscored that Delfi was 'a professionally managed Internet news portal run on a commercial basis which sought to attract a large number of comments on news articles published by it' ${ }^{24}$ The dissenting judges aptly argued that the economic activity of the news portal does not cancel out the potential of comment sections for facilitating individual contributions to public debate in a way that 'does not depend on centralised media decisions' ${ }^{25}$

Fourthly, the Court was at pains to stress that 'the case does not concern other fora on the Internet where third-party comments can be disseminated . ., ${ }^{26}$ but again, this did not wash for the dissenting judges. ${ }^{27}$

It is noteworthy that the Court has distinguished the Delfi case and a string of subsequent cases on the basis of the nature of the comments. Whereas it had found that some of the comments in Delfi amounted to hate speech, it described the comments at issue in the MTE \& Index.hu case as 'offensive and vulgar', but found that they 'did not constitute clearly unlawful speech' and 'certainly did not amount to hate speech or incitement to violence'. ${ }^{28}$ The Court followed this line in its inadmissibility decision in Pihl $v$ Sweden, a case involving a defamatory blogpost and an anonymous online comment. ${ }^{29}$ Similarly, in Savva Terentyev $v$

${ }^{24}$ ibid. para. 144.

${ }^{25}$ ibid. Joint Dissenting Opinion paras 39 and 28.

${ }^{26}$ ibid. para. 116.

${ }^{27}$ ibid. Joint Dissenting Opinion para. 9.

${ }^{28}$ Magyar (n. 11) para. 64.

${ }^{29}$ See Pihl v Sweden (dec.) App. no. 74742/14 (ECtHR, 7 February 2017). 
Russia, the Court did not hide its repulsion at the language at the centre of the case, describing it as 'framed in very strong words' and as 'largely [using] vulgar, derogatory and vituperative terms' $\cdot{ }^{30}$ However, after deep contextual examination, it did not classify the impugned expression as 'hate speech'. The impugned expression was a diatribe against the police, posted as a comment on an online blog.

This distinction between offensive and vulgar expression and hate speech is of major significance, even if it is sometimes difficult to determine in practice. Hate speech - and other types of extreme speech such as incitement to violence and/or terrorist activities - may justify far-reaching restrictions on freedom of expression and imply heightened responsibilities for internet intermediaries to prevent the dissemination of such types of expression via their sites and services. This, at least, seems to be the Court's approach in the Delfi case and its progeny.

Besides the ECHR, the Council of Europe uses various other instrumentsother treaties and political standard-setting texts — to address media and internet freedom and regulation. The Committee of Ministers, for instance, has adopted numerous Declarations and Recommendations dealing with topics such as a new notion of media; freedom of expression, association, and assembly with regard to privately operated internet platforms and online service providers; human rights and search engines, and human rights and social networking services. Among these political standard-setting texts, there is a discernible - and growingemphasis on the responsibilities of internet intermediaries.

${ }^{30}$ Savva Terentyev v Russia App. no. 10692/09 (ECtHR, 28 August 2018) para. 67. See also Pihl v Sweden (n. 29) para. 73. 
For instance, in its Recommendation CM/Rec(2018)2 to Member States on the roles and responsibilities of internet intermediaries, the Committee of Ministers observes that internet intermediaries 'facilitate interactions on the internet between natural and legal persons by offering and performing a variety of functions and services'. ${ }^{31}$ If further states that '[o]wing to the multiple roles intermediaries play, their corresponding duties and responsibilities and their protection under law should be determined with respect to the specific services and functions that are performed.' 32

In its Appendix, the Recommendation sets out detailed and extensive Guidelines for states on actions to be taken vis-à-vis internet intermediaries with due regard to their roles and responsibilities. The Guidelines have a dual focus: obligations of states and responsibilities of internet intermediaries. The identified obligations of states include ensuring: the legality of measures adopted, legal certainty and transparency, safeguards for freedom of expression, privacy and data protection, and access to an effective remedy. The responsibilities of internet intermediaries include: respect for human rights and fundamental freedoms, transparency and accountability, responsibilities in respect of content moderation, the use of personal data, and ensuring access to an effective remedy.

\subsection{The European Union}

\footnotetext{
$31<$ ibt>Recommendation CM/Rec(2018)2 of the Committee of Ministers to member States on the roles and responsibilities of internet intermediaries (7 March 2018) Preamble</ibt>, para. 4.

32 ibid. para. 11.
} 
The EU, too, has a multilayered regulatory framework containing provisions on freedom of expression, the media, and internet intermediaries. It comprises primary and secondary EU law, as well as non-legislative acts, and is supplemented by self- and co-regulatory mechanisms. A selection of the framework's most salient focuses will now be presented by way of general overview.

The Charter of Fundamental Rights of the European Union is the EU's flagship instrument for the protection of human rights. Since the entry into force of the Lisbon Treaty at the end of 2009, the Charter has acquired the same legal status as the EU Treaties, thereby enhancing its relevance. The Charter's provisions 'are addressed to the institutions, bodies, offices and agencies of the Union with due regard for the principle of subsidiarity and to the Member States only when they are implementing Union law' (Art. 51(1)). The Charter's provisions 'which contain principles may be implemented by legislative and executive acts taken by institutions, bodies, offices and agencies of the Union, and by acts of Member States when they are implementing Union law, in the exercise of their respective powers' (Art. 52(5)). However, they shall be 'judicially cognisable only in the interpretation of such acts and in the ruling on their legality' (ibid.). Insofar as the Charter recognizes fundamental rights resulting from the constitutional traditions common to EU Member States, those rights shall be interpreted in harmony with those traditions (Art. 52(4)).

It is important to ensure that the human rights standards elaborated by the Council of Europe and the EU are broadly consistent or equivalent. This is important from the point of view of legal consistency within Europe. In keeping 
with this line of thinking, the Charter provides that insofar as the Charter contains rights that correspond to those safeguarded by the ECHR, 'the meaning and scope of those rights shall be the same as those laid down by' the Convention (Art. 52(3)). This reference to the Convention includes the case law of the European Court of Human Rights. ${ }^{33}$ Article 11 of the Charter-which focuses on freedom of expression, as well as media freedom and pluralism—should therefore be interpreted consistently with Article 10 of the Convention and relevant case law of the European Court of Human Rights. The text of Article 11 of the Charter is in any case modelled on Article 10 of the Convention, but is more succinctly formulated. All of this means that the principles from relevant case law of the European Court of Human Rights (set out earlier) ought to govern the interpretation of Article 11 of the Charter by the Court of Justice of the European Union (CJEU).

At the level of secondary EU law, a number of Directives are relevant, in particular the e-Commerce Directive and the Audiovisual Media Services Directive.

The main aim of the e-Commerce Directive is to seek 'to contribute to the proper functioning of the internal market by ensuring the free movement of information society services between the Member States' ${ }^{34}$ The Directive is ${ }^{33}$ EU Network of Independent Experts on Fundamental Rights, Commentary of the Charter of Fundamental Rights of the European Union (2006) 400.

$34<$ ibt>Directive 2000/31/EC of the European Parliament and of the Council of 8 June 2000 on certain legal aspects of information society services, in particular electronic commerce, in the Internal Market [2000] OJ L178/1</ibt>, Art. 1. 
premised on a contemporary understanding of how internet intermediaries worked in 2000 when the Directive was adopted, namely that intermediaries either have a passive or an active relationship with third party content disseminated through their networks or services. In the logic of this binary distinction, the drafters of the Directive sought to ensure that passive intermediaries would not be held liable for content over which they had no knowledge or control. The Directive thus establishes a 'safe harbour' regime for passive intermediaries.

The safe harbour regime entails exemptions from liability in "cases where the activity of the information society service provider is limited to the technical process of operating and giving access to a communication network over which information made available by third parties is transmitted or temporarily stored, for the sole purpose of making the transmission more efficient; this activity is of a mere technical, automatic and passive nature, which implies that the information society service provider has neither knowledge of nor control over the information which is transmitted or stored' ${ }^{35}$ These exemptions are set out in Articles 12 to 14 of the Directive and they can be availed of by service providers acting as a 'mere conduit' for information, or those which provide 'caching' or 'hosting' services. This means that intermediaries which serve as hosting providers would ordinarily benefit from an exemption for liability for illegal content, as long as they maintain a neutral or passive stance towards that content. A service provider that hosts third party content may avail of this exemption on condition that it does not have 'actual knowledge of illegal activity or

35 ibid. recital 42. 
information and, as regards claims for damages, is not aware of facts or circumstances from which the illegal activity or information is apparent' and that 'upon obtaining such knowledge or awareness, acts expeditiously to remove or to disable access to the information'. ${ }^{36}$ However, 'the removal or disabling of access has to be undertaken in the observance of the principle of freedom of expression and of procedures established for this purpose at national level'. ${ }^{37}$ Pursuant to Article 15 of the Directive, EU Member States are not allowed to impose a general obligation on providers to 'monitor the information which they transmit or store, nor a general obligation actively to seek facts or circumstances indicating illegal activity'. The type of surveillance that such a general monitoring obligation would entail would have a chilling effect on the freedom of expression of users of the service.

The binary distinction between passive and active intermediaries that informed the drafting of the e-Commerce Directive has long been under strain. It no longer adequately reflects the complexity of the relationship between intermediaries and third party content today. Ongoing technological developments have enabled intermediaries to engage in a range of activities that move beyond passive hosting towards presentational, recommendation, ranking, and editorial functions. Such activities place the binary distinction under strain because exemption from liability is based on an objective distance from content created by third party users.

\footnotetext{
36 ibid. Art. 14.

${ }^{37}$ ibid. recital 46.
} 
The Audiovisual Media Services Directive seeks to ensure a minimum level of harmonization across the EU of national legislation governing audiovisual media services, with a view to removing obstacles to the free movement of such services within the EU's single market. In pursuance of these aims, the Directive coordinates a number of areas: general principles; jurisdiction; incitement to hatred; accessibility for persons with disabilities; major events; the promotion and distribution of European works; commercial communications; and protection of minors.

The Directive has evolved from the former Television without Frontiers Directive, and covers traditional television broadcasting as well as on-demand audiovisual media services. Following the revision of the Directive in 2018, the providers of video-sharing platform services will henceforth also fall under the scope of the Directive, insofar as they are covered by the definition of such services. The definition is rather convoluted:

'video-sharing platform service' means a service as defined by Articles 56 and 57 of the Treaty on the Functioning of the European Union, where the principal purpose of the service or of a dissociable section thereof or an essential functionality of the service is devoted to providing programmes, user-generated videos, or both, to the general public, for which the video-sharing platform provider does not have editorial responsibility, in order to inform, entertain or educate, by means of electronic communications networks within the meaning of point (a) of Article 2 of Directive 2002/21/EC and the organisation of which is 
determined by the video-sharing platform provider, including by automatic means or algorithms in particular by displaying, tagging and sequencing.

The thinking behind this shift is that privately owned internet intermediaries exert organizational control over third party content; they determine the modalities of how that content is made available, its level of prominence, and so on. If they de facto control what their users see and how they see it, they should also be held responsible or liable for the content—even though they do not have editorial control over it. Recital 47 of the Directive spells out this thinking in relation to video-sharing platforms in the context of the Directive:

A significant share of the content provided on video-sharing platform services is not under the editorial responsibility of the video-sharing platform provider. However, those providers typically determine the organisation of the content, namely programmes, user-generated videos and audiovisual commercial communications, including by automatic means or algorithms. Therefore, those providers should be required to take appropriate measures to protect minors from content that may impair their physical, mental or moral development. They should also be required to take appropriate measures to protect the general public from content that contains incitement to violence or hatred directed against a group or a member of a group on any of the grounds referred to in Article 21 of the Charter of Fundamental 
Rights of the European Union (the 'Charter'), or the dissemination of which constitutes a criminal offence under Union law.

This line of thinking has been criticized for resulting in 'considerable political and social pressure [being] exerted on these platforms to resolve the problems "themselves"". ${ }^{38}$ This, in turn, "leads to a "spiral of privatised regulation". 39

The applicability of the Directive to the providers of video-sharing platform services does not concern all provisions of the Directive. The focus is very much on content that is damaging for minors, incitement to violence or hatred, and public provocation to commit a terrorist offences (but there is also attention for requirements for audiovisual commercial communications). Article $28 \mathrm{~b}$ is the operative provision in this regard. It reads:

$<$ lext $>1$. Without prejudice to Articles 12 to 15 of Directive 2000/31/EC, Member States shall ensure that video- sharing platform providers under their jurisdiction take appropriate measures to protect:

(a) minors from programmes, user-generated videos and audiovisual commercial communications which may impair their physical, mental or moral development in accordance with Article 6a(1);

$38<$ ibt>Ben Wagner, 'Free Expression? Dominant Information Intermediaries as Arbiters of Internet Speech' in Martin Moore and Damian Tambini (eds), Digital Dominance: the Power of Google, Amazon, Facebook, and Apple (OUP 2018) 223</ibt $>$.

39 ibid. 
(b) the general public from programmes, user-generated videos and audiovisual commercial communications containing incitement to violence or hatred directed against a group of persons or a member of a group based on any of the grounds referred to in Article 21 of the Charter;

(c) the general public from programmes, user-generated videos and audiovisual commercial communications containing content the dissemination of which constitutes an activity which is a criminal offence under Union law, namely public provocation to commit a terrorist offence as set out in Article 5 of Directive (EU) 2017/541, offences concerning child pornography as set out in Article 5(4) of Directive 2011/93/EU of the European Parliament and of the Council (*) and offences concerning racism and xenophobia as set out in Article 1 of Framework Decision 2008/913/JHA. $</$ lext $>$

Bringing video-sharing platform providers under the Directive stretches both the material scope and the underlying logic of the Directive. Be that as it may, the move reflects a clear anxiety about the prevalence of particular types of harmful content on video-sharing platforms and their influence on the public. The move seeks to ensure that the selected types of harmful content cannot slip through any regulatory meshes between the nets of the e-Commerce Directive and the Audiovisual Media Services Directive. The three types of harmful content have been singled out for far-reaching restrictions over and above other types of (less) 
harmful content. A similar distinction in the case law of the European Court of Human Rights has also been observed (see further earlier in the chapter).

Besides the aforementioned Directives - both of which are traditional forms of regulation, it is also apposite to pay attention to self- and co-regulatory systems, and non-legislative measures in this area. The European Union has a history of advocating the use of self-regulatory mechanisms as the most appropriate form of regulating the internet and mobile technologies, due to constant technological developments in those areas. According to the revised Audiovisual Media Services Directive: 'Self-regulation constitutes a type of voluntary initiative which enables economic operators, social partners, nongovernmental organisations and associations to adopt common guidelines amongst themselves and for themselves. They are responsible for developing, monitoring and enforcing compliance with those guidelines' (recital 14).

Self-regulation, with the flexibility it offers, is seen as a suitable means of regulating certain aspects of media, internet, and mobile technologies. For instance, the Audiovisual Media Services Directive (Art. 4a) encourages EU Member States to explore the suitability of self- and/or co-regulatory techniques. ${ }^{40}$ Similarly, both the e-Commerce Directive (Art. 16) ${ }^{41}$ and the

${ }^{40}$ See Directive 2010/13/EU of the European Parliament and of the Council of 10 March 2010 on the coordination of certain provisions laid down by law, regulation or administrative action in Member States concerning the provision of audiovisual media services (Audiovisual Media Services Directive) (codified version) [2010] OJ L95/1, as revised by Directive 2018/1808 of 14 November 2018, [2018] OJ L-303/69. 
former Data Protection Directive (Art. 27) ${ }^{42}$ (have) stress(ed) the importance of codes of conduct; approaches which represent a tentative move away from traditional regulatory techniques in the direction of self-regulation.

\section{GEOMETRICAL SHIFTS}

For several decades, the mass media — print and broadcast — held sway as 'the central institution of a democratic public sphere'. ${ }^{43}$ In today's increasingly digitized society, the mass media have ceded that position to, or are at least sharing it with, a growing number of other new media actors. These actors do not usually fall within the ambit of traditional media regulatory regimes. This has made it much more challenging to regulate expression in the online environment. $^{44}$

${ }^{41}$ See Directive 2000/31/EC of the European Parliament and of the Council of 8 June 2000 on certain legal aspects of information society services, in particular electronic commerce, in the Internal Market (e-Commerce Directive) [2000] OJ L178/1

${ }^{42}$ See Directive 95/46/EC of the European Parliament and of the Council of 24 October 1995 on the protection of individuals with regard to the processing of personal data and on the free movement of such data [1995] OJ L281/31.

${ }^{43}$ Edwin Baker, 'Viewpoint Diversity and Media Ownership' (2009) 60 Federal Communications L.J. 651, 654.

${ }^{44}$ See Egbert Dommering, 'The Ever Growing Complexity of Regulating the Information Society' in Pieter Kleve and Kees van Noortwijk (eds), Something 
Internet intermediaries are important actors in the online environment. Due to their gate-keeping functions, they can facilitate or obstruct access to the online fora in which public debate is increasingly conducted. ${ }^{45}$ Intermediaries with search and/or recommendation functions, typically driven by algorithms, have far-reaching influence on the availability, accessibility, visibility, findability, and prominence of particular content. The operators of social network services, for instance, 'possess the technical means to remove information and suspend accounts', which makes them 'uniquely positioned to delimit the topics and set the tone of public debate' ${ }^{46}$ Search engines, for their part, have the aim and the ability to make information more accessible and prominent; which gives them influence over how people find information and ideas and over what kinds of

Bigger than Yourself_Essays in Honour of Richard de Mulder (Erasmus Universiteit Rotterdam 2011) 1-15.

${ }^{45}$ See e.g. Aleksandra Kuczerawy, Intermediary Liability and Freedom of Expression in the EU: from Concepts to Standards (Intersentia 2018) chs 1 and 2.

${ }^{46}$ See Patrick Leerssen, 'Cut Out by The Middle Man: The Free Speech Implications of Social Network Blocking and Banning in the EU' (2015) 6 JIPITEC 99, 99-100. 
information and ideas they find. ${ }^{47}$ Both of these types of internet intermediary therefore have clear 'discursive significance' in society. ${ }^{48}$

The term 'online platform' is being used increasingly in scholarship, sometimes thoughtfully and sometimes loosely, to denote a particular type of online actor. The term has come to the fore in policymaking discussions and processes. It has been described as 'a programmable digital architecture designed to organize interactions between users - not just end users but also corporate entities and public bodies'. ${ }^{49}$ It is furthermore 'geared toward the systematic collection, algorithmic processing, circulation, and monetization of user data' ${ }^{50}$ The combination of actions and interactions enabled by platforms, and their complexity, demonstrate that they are qualitatively different to traditional media, and that the regulatory framework for traditional media cannot straightforwardly be extended to online platforms.

Some authors speak of the datafication and platformization of society and the Internet of Things. Ongoing developments and trends have prompted the observation that '[p]latform mechanisms shape every sphere of life, whether

${ }^{47}$ See generally Joris van Hoboken, Search Engine Freedom. On the Implications of the Right to Freedom of Expression for the Legal Governance of Web Search Engines (Kluwer Law Int'1 2012).

$48<$ ibt>Emily Laidlaw, Regulating Speech in Cyberspace: Gatekeepers, Human Rights and Corporate Responsibility (CUP 2015)</ibt> 204.

49 ibid. 4.

50 ibid. 
markets or commons, private or public spheres' ${ }^{51}$ All of this is pointing towards the dislodging of the mass media as the central institution in democratic societies. A more abundant, but fragmented, information offer has emerged instead, with new gate-keepers controlling its flow.

Internet intermediary liability has been the subject of extensive academic examination, from a variety of perspectives, such as accountability issues, ${ }^{52}$ tort law, ${ }^{53}$ freedom of expression, ${ }^{54}$ and copyright. ${ }^{55}$ Some authors have detected a recent shift of focus in (the discourse around) relevant lawmaking and policymaking. They have pointed to an ongoing movement from intermediary and platform liability to responsibility. ${ }^{56}$

${ }^{51}$ (Emphasis in original) José van Dijck, Thomas Poell, and Martijn de Waal, The Platform Society: Public Values in a Connective World (OUP 2018) 46.

${ }^{52}$ See Martin Husovec, Injunctions Against Intermediaries in the European Union-Accountable But Not Liable? (CUP 2017).

${ }^{53}$ See e.g. Christina Angelopoulos, European Intermediary Liability in Copyright. A Tort-Based Analysis (Kluwer Law Int'1 2017).

${ }^{54}$ See e.g. Aleksandra Kuczerawy, Intermediary Liability and Freedom of Expression in the EU: from Concepts to Standards (Intersentia 2018).

${ }^{55}$ See e.g. Stefan Kulk, 'Internet Intermediaries and Copyright Law: Towards a Future-proof EU Legal Framework', PhD thesis, Utrecht University (2018).

${ }^{56}$ See Giancarlo Frosio, 'Why Keep a Dog and Bark Yourself? From Intermediary Liability to Responsibility’ (2018) 26(1) IJLIT 1, 8; Aleksandra Kuczerawy, Intermediary Liability and Freedom of Expression in the EU: 
This is an insightful reading of current regulatory and policy discussions and developments. At the Council of Europe, the Delfi judgment underscored the requirement for certain types of internet intermediaries to take strong and effective measures against hate speech (although the Grand Chamber of the Court was at pains to stress that the wider ramifications of the judgment were limited). Standard-setting instruments by the Committee of Ministers stress that the human rights responsibilities of internet intermediaries should guide all of their activities.

Under EU law, the revised Audiovisual Media Services Directive has created new obligations for video-sharing platforms to prevent the dissemination of certain types of harmful illegal content via their services. The new Directive on copyright and related rights in the Digital Single Market also contains provisions that create liability for internet intermediaries for unauthorized communication to the public of copyrighted works. ${ }^{57}$ Under Article 17 of the Directive, 'online content-sharing service providers shall be liable for unauthorised acts of communication to the public, including making available to the public, of copyright-protected works and other subject matter', save in certain limited

from Concepts to Safeguards (Intersentia 2018). See also John Naughton, 'Platform Power and Responsibility in the Attention Economy' in Martin Moore and Damian Tambini (eds), Digital Dominance: the Power of Google, Amazon, Facebook, and Apple (OUP 2018) 371-95.

${ }^{57}$ See Directive 2019/790/EU of the European Parliament and of the Council of 17 April 2019 on copyright and related rights in the Digital Single Market and amending Directives 96/9/EC and 2001/29/EC [2019] OJ L130/92. 
circumstances. This provision has sparked fears that it will lead in practice to the installation of upload filters to pre-empt the sharing of copyright-protected works in a strategy to avoid liability for the unauthorized communication to the public of such works.

These legislative developments continue a wider-sweeping policy line set out by the European Commission in its Communication, 'Tackling Illegal Content Online: Towards an enhanced responsibility of online platforms' ${ }^{58}$ The title of the Communication accurately encapsulates its intent. The Communication provides guidance to online service providers in respect of their responsibilities vis-à-vis illegal online content. The Commission took the opportunity to announce that it would assess whether additional measures were needed, including by monitoring progress on the basis of existing voluntary arrangements among service providers. The Communication was followed by a Recommendation on measures to effectively tackle illegal content online, which 'builds on and consolidates the progress made in the framework of voluntary arrangements agreed between hosting service providers and other affected service providers regarding different types of illegal content' ${ }^{59}$

Other current legislative proposals similarly follow this policy line, for example the proposal for a Regulation of the European Parliament and of the

${ }^{58}$ See European Commission, 'Tackling Illegal Content Online-Towards an enhanced responsibility of online platforms' (28 September 2017) COM (2017) 555 final.

${ }^{59}$ European Commission, 'Recommendation on Measures to Effectively Tackle Illegal Content Online' (1 March 2018) C (2018) 1177 final. 
Council on preventing the dissemination of terrorist content online. ${ }^{60}$ The proposed Regulation seeks to 'provide clarity as to the responsibility of hosting service providers in taking all appropriate, reasonable and proportionate actions necessary to ensure the safety of their services and to swiftly and effectively detect and remove terrorist content online, taking into account the fundamental importance of the freedom of expression and information in an open and democratic society'. ${ }^{61}$

This new wave of EU law and policy consistently mentions the need to take into account or have regard for fundamental rights safeguards and existing provisions for exemptions for liability under the e-Commerce Directive. It is very important that this does not become mere lip-service and that the new wave of EU law and policy does not wash over or wash away fundamental rights safeguards. ${ }^{62}$

${ }^{60}$ See <ibt>European Commission, 'Proposal for a Regulation of the European Parliament and of the Council on Preventing the Dissemination of Terrorist Content Online' (12 September 2018) COM (2018) 640 final, 2018/0331 $(\mathrm{COD})</$ ibt $>$ para. 2.

${ }^{61}$ ibid. 2.

${ }^{62}$ See generally Christina Angelopoulos and others, 'Study of fundamental rights limitations for online enforcement through self-regulation', commissioned by Open Society Foundations, Institute for Information Law (2015). See also, in particular as regards the proposal for a Regulation on preventing the dissemination of terrorist content online, European Union Agency for 
A selection of policy and ostensibly self-regulatory initiatives deserve mention at this juncture as they are indicative of one of the main ongoing shifts in the geometry of European regulation, namely codes of conduct against online hate speech and online disinformation. In May 2016, at the behest of the European Commission, the Code of Conduct on Countering Illegal Hate Speech Online was adopted by a number of leading multinational tech companies. The initial signatories were Facebook, Microsoft, Twitter, and YouTube (owned by Google), with other companies joining later: Instagram (owned by Facebook), Google+, Snapchat, and Dailymotion in 2018 and Jeuxvideo.com in 2019. Under the Code, the signatory IT companies commit inter alia 'to review the majority of valid notifications for removal of illegal hate speech in less than 24 hours and remove or disable access to such content, if necessary'. Compliance with the Code is monitored by way of annual evaluations; the fourth evaluation took place in December 2018. As in the previous annual evaluations, the Commission and the IT companies were self-congratulatory about the high statistics provided about the speed of reviewing and high removal rate of illegal hate speech from their services. The IT companies review an average of 89 per cent of notifications of illegal hate speech within twenty-four hours and they are removing 72 per cent of the illegal hate speech notified to them. ${ }^{63}$

Fundamental Rights, Opinion 2/2019—Online Terrorist Content (February 2019).

${ }^{63}$ See European Commission, 'Code of Conduct on countering illegal hate speech online: Fourth evaluation confirms self-regulation works, Fact sheet' (February 2019). 
The aim and achievement of cleaning up the internet's cesspools ${ }^{64}$ is laudable, and the expeditious removal or disabling of hate speech from online networks is to be welcomed. However, concerns persist about the risk of private censorship by the actors responsible for the decisions to remove or disable particular types of content. There is particular concern about the risk of overcensorship and the removal of content 'to be on the safe side' and to thereby avoid incurring liability for such content. Reporting under the Code reveals little about the processes and criteria used to make such decisions - despite the Code's professed commitment to enhancing the transparency of such processes. The focus of the IT companies' reporting so far has been predominantly on statistics about the removal of content and less on other commitments under the Code that could contribute to creating an online environment that is more resilient in the face of hate speech. Examples include education and awareness-raising and the promotion of independent counter-narratives. It is important to appreciate and pay attention to the range of responsibilities of the IT companies and not to fixate on removal statistics. Existing European and international standards on business and human rights underscore the need for a broad understanding of the range of responsibilities at issue. ${ }^{65}$ It is important for the IT companies to demonstrate

${ }^{64}$ See Brian Leiter, 'Cleaning Cyber-Cesspools: Google and Free Speech' in Saul Levmore and Martha Nussbaum (eds), The Offensive Internet: Speech, Privacy, and Reputation (HUP 2010) 155-73.

${ }^{65}$ See United Nations Guiding Principles on Business and Human Rights (2011); Council of Europe, 'Recommendation CM/Rec(2016)3 of the Committee of Ministers to member States on human rights and business (2 March 2016) 
positional awareness within relevant European and international standards when honouring their commitments under the Code.

At the end of September 2018, representatives of several online platforms, social networking service operators and advertising companies agreed on a Code of Practice on Disinformation. This initiative should be seen in the context of a wider range of efforts by the EU to combat online disinformation, including the Commission’s Communication, ‘Tackling online disinformation: a European approach' (April 2018), and an Action Plan against Disinformation (December 2018). Google, Facebook, Twitter, Mozilla, and the trade associations representing the advertising sector submitted their first reports on the measures they are taking to comply with the Code of Practice on Disinformation at the end of January 2019. ${ }^{66}$ The European Commission gave the reports a guarded welcome, while urging the signatories to improve and/or increase the measures they have taken. Each signatory chooses the most relevant commitments for its own company - in the light of the services it offers and actions it performs - from a list of possible commitments. The Commission has reminded/cautioned the signatories about the possibility of a legislative backstop in this area. The Commission has stated that should the results of the envisaged comprehensive,

$\mathrm{CM} / \operatorname{Rec}(2016) 3$; Council of Europe, 'Recommendation CM/Rec(2018)2 of the Committee of Ministers to member States on the roles and responsibilities of internet intermediaries' (7 March 2018) CM/Rec(2018)2.

${ }^{66}$ See European Commission, 'First results of the EU Code of Practice against disinformation’ (29 January 2019) <https://ec.europa.eu/digital-singlemarket/en/news/first-results-eu-code-practice-against-disinformation>. 
twelve-month assessment of the operation of the Code of Practice in December 2019 prove unsatisfactory, it may take further action, including of a regulatory nature.

\section{CONCLUSIONS}

It is little wonder that the Council of Europe and the European Court of Human Rights are moving tentatively from one shore to another in their approach to media freedom and regulation in the digital age. As the Delfi judgment appears to put greater onus on internet intermediaries - in particular circumstances - to tackle hate speech over which they can exert control, it is essential not to lose sight of the free expression principles that have guided the Court's approach in the analogue world. That the Court has emphasized those principles repeatedly in the post-Delfi case law may suggest that the critical backlash against that judgment has not gone unheard within the Court. The Committee of Ministers is pushing for internet intermediaries to show a greater sense of ambition and initiative when it comes to identifying and fulfilling their human rights responsibilities.

A continuing challenge and source of tension involves the delineation of the term hate speech; that is, the demarcation line between types of harmful expression that ordinarily are entitled to protection and the most harmful types of expression that attack the values of the ECHR and therefore do not enjoy protection. It is very important that the Court provides as much clarity and clarification as possible, in the light of the growing expectations on internet intermediaries to take effective measures to counter and prevent hate speech, 
terrorist content, and other such content. There is a correlation between the seriousness of the perceived harms of certain categories of expression and the expectation of heightened responsibility on the part of internet intermediaries to provide effective protection against them.

This is precisely the dilemma that is dogging the current EU approach, which is increasingly shifting the burden of policing content to private actors because they have the technical capacity to take preventive and removal/blocking actions. However, the lack of legal legitimacy of private actors to carry out such public tasks and the absence of transparency and accountability for how they actually exercise their censorial power in this regard, raises a range of pressing fundamental rights concerns. Internet intermediaries are now coming under increasing pressure to live up to their corporate social and human rights responsibilities in markets where their corporate interests dominate, but where there is a pending possibility of sanctions and/or regulation to put steel into voluntary commitments entered into by intermediaries.

The regulatory geometry of internet intermediaries is complex and multidimensional. It is shifting from the relative confidence in a binary understanding of passive and active actors to an anxious awe of complicated, multi-functional platforms which have reshaped the whole ecosystem in which they operate. More shifts in these geometrical patterns are to be expected in order to deal with the ongoing platformization of public debate. 